\title{
BECOMING AN ORANG INDONESIA SEJATI: THE POLITICAL JOURNEY OF YAP THIAM HIEN
}

\author{
Daniel S. Lev
}

Djikaloe pranakan Tionghoa dengan mendengar soeara hatinja maoe lengketken nasibnja bersama-sama orang Indonesier pada tana Indonesia ini, ia poen moesti dianggap Indonesier sedjati.

-Liem Koen Hian, 1934.

Once the curtain of common myths about peranakan Chinese in Indonesia is parted sensibly on reality, what appears is a startlingly complex presence in local history, filled with the kinds of contradiction, tension, strength, vulnerability, and tragedy that seem always to surround such diasporas. To say that Indonesian Chinese have enriched Indonesia is a misleading cliché, for it sets them apart still as something other than Indonesian. For the most part, they are understandable nowhere else, as is true of most national minorities anywhere. If they are not unique, they are at least different, as Indonesians generally are different from anybody else.

As it happens, the man I discuss in this paper is about as different from anybody else, in important ways, as one can imagine and yet is more or less understandable in Indonesiaand to many is an authentic Indonesian hero. One measure of his achievement is that by the end of his life, in April 1989, at age seventy-six, few thought his Chinese origins relevant to anything important or even all that interesting. For many of the thousands who mourned him, and certainly for those who created a small furor at his graveside-shouting that this man belonged to the nation, not just his family-Yap had become an extraordinary symbol of the struggle for political change in Indonesia. It did not matter that his name was Yap.

For critical comments, information, and advice on this paper, although I have not been able to absorb all of it, I am grateful to T. Mulya Lubis, Oei Tjoe Tat, Siauw Tiong Djin, Leo Suryadinata, Harry Tjan Silahi, Charles Hirschman, and Arlene O. Lev.

The quotation from Liem is translated as follows: If peranakan Chinese, heeding their hearts, want to join fates together with Indonesians, then they too must be considered true Indonesians. 
Yet Yap came to the national scene of Indonesian politics rather late, only in the 1960s, after an apprenticeship in the sideshow of peranakan politics. By no means was he the only one to do so, but his course was peculiar enough to merit attention, in part because one can trace the ideas that guided him through it. Although his early biography is sketched here, the main focus will be on a few issues that marked his way out of a minority periphery towards the national center. For the sake of contrast, much of the paper is built around the tension between Yap and the late Siauw Giok Tjhan, chairman of the peranakan political organization Baperki (Badan Permusjawaratan Kewarganegaraan Indonesia) from its inception in 1954 until it was banned in 1966. For several years these two extraordinary men dominated one range of conflict over a wider continuum of peranakan political experience and thought.

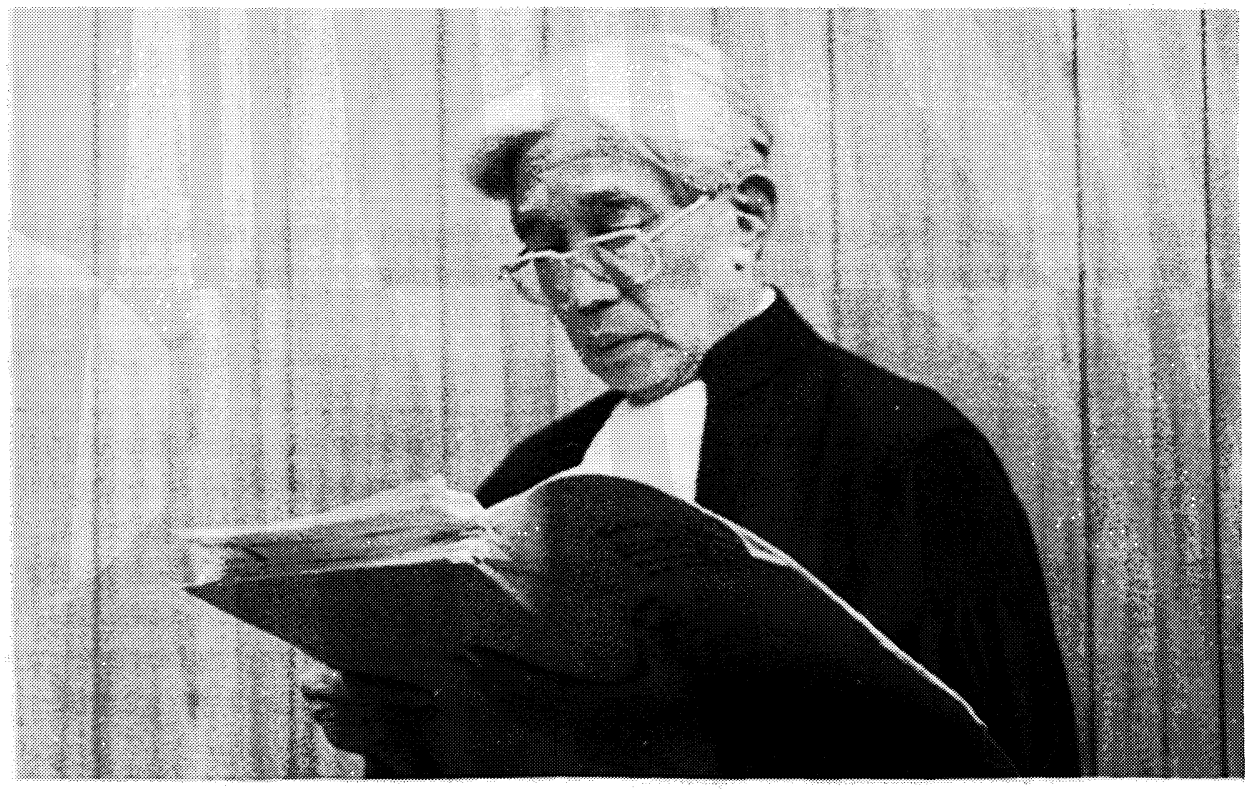

Yap Thiam Hien

As a prelude to a discussion that concentrates on one or two leading figures, rather than peranakan society in general, it may be useful to recall that Indonesian Chinese have never formed a well-integrated community. Other similarly positioned minorities around the world have enjoyed (not always to great advantage) more religious and cultural integrity, or at least less diversity. Peranakan Chinese in Indonesia are disparate: geographically spread, religiously and culturally variegated, historically experienced, and locally absorbed and formed in different ways. Group recognition exists, of course, along with ethnic identity-as often as not enforced by external hostility and pressure-but there is relatively little vertical 
and horizontal solidarity, however differently outside impressions may have it. The social and political history of Indonesian Chinese demonstrates this point well enough. Hard as it is to avoid using the term "the Chinese" or some other inadequate analogue-peranakan, Warga Negara Indonesia (WNI), Indonesian Chinese, keturunan-one ought to hold in mind that it almost always produces a caricature, often a racist one at that. ${ }^{1}$

In Yap Thiam Hien's case, except for the presence of an odd foster grandmother, his early life was unexceptional in one stratum of peranakan Chinese society, yet it would seem peculiar anywhere but in the stream of twentieth-century Indonesian history. Three or four items from his biography may help to account for the kind of man he became.

He was well born to the wealth, privilege, and comforts of an officier family in Banda Aceh in 1913, but just at the time when the privileges of the officieren were beginning to disappear under the dual pressures of middle class Chinese political awakening and colonial social reforms. His great-grandfather, the Luitenant, who had immigrated from Guangdong to Bangka and somehow ended up in Aceh, did well mainly (one suspects) from the opium monopoly, but once this disappeared, he, like many other officieren around the colony, lost the family stake through commercial misadventure-in his case, coconut plantations, then an egregiously bad investment in Aceh. (Then and later, many peranakan, by contrast with immigrant totok, gave the lie to the myth of Chinese business prowess, but commercial ineptitude seems to have run especially deep in the Yap line.) Bankrupt, the family lost its position in 1920 to another family, the Han, imported from East Java.

Not long afterwards, when he was nine, Yap's young mother died. He and his younger brother and sister fell to the care of his grandfather's mistress, a Japanese woman, Sato Nakashima, whom the Yap children came to think of as mother, father, and grandmother all in one. If nothing else set Yap apart from others, a Japanese grandmother did, but she was evidently a remarkable person in her own right. There is no space here to trace her influence on the character of the three children, but it was substantial. She provided them, along with much else, the kind of intimacy that extended Chinese families usually lacked, as well as a fairly firm ethical sense that may explain a great deal about the mature Yap.

His father, Sin Eng, the first real peranakan in the Yap line, was a weak figure who won little respect from his son. A trite psychoanalyst might conclude that the mature Yap Thiam Hien was quick to challenge authority because of his relationship with Yap Sin Eng-and might be right, though the authorities whom Yap fought also deserve some credit. If nothing else, however, Sin Eng helped to mold Thiam Hien's life by adopting Dutch legal status (gelijkstelling) for his family. European status guaranteed the children's rights to a European education after the family lost its officier status. Yap's education in the schools for Europeans and privileged others was superb, from the ELS primary school in Kutaraja (Banda Aceh), through MULO in Batavia, where his father moved in the 1920s, and on to the AMSA/2 (Western languages) program in Bandung and Yogyakarta. His education, like his advantaged birth, left him confident and ambitious but also socially at loose ends, for the European education and ethnically mixed experience was followed by few appropriate nonethnic lines of opportunity. None of this was unusual in the small stratum of highly educated non-Europeans in the colony.

\footnotetext{
${ }^{1}$ In Indonesia far more so than in Malaysia, for example, but closer to the Thai, Vietnamese, and Philippine cases, peranakan Chinese are not always easily distinguished from ethnic Indonesians. Sometimes this is as true physically as it is culturally, for many, like Yap himself, have mixed genes, to put it bloodlessly.
} 
In one way or another most were culturally marginalized. ${ }^{2}$ For Yap, however, there was little to fall back on. Raised in Aceh but having moved to Jakarta, he had no extended family in Java and little enough of a nuclear family, for only he and his father and brother were there until Sato Nakashima and his sister came in the late 1930s. This may help to explain his conversion to Protestantism in 1938, after his introduction to it a few years earlier in the loving Eurasian family with whom he lived in Yogya. ${ }^{3}$ The church, a Chinese Hervormde Kerk (Reformed Church) in Jakarta, and associated nonethnic organizations provided him with a secure base that he took to enthusiastically, though he understood little of modern Dutch Calvinism until he began to read and talk about it assiduously in Holland after the war.

As in the church, his vocational chances were also tracked into a Chinese stream. The colonial policy of separating and thus creating ethnic camps made it difficult to cross lines. The most obvious opportunity for Yap, failing work elsewhere during the depression, was in the Dutch-Chinese Teachers School (HCK) in Jakarta, which prepared him to teach in the Dutch-Chinese schools (HCS). Finishing the HCK curriculum in one year, he taught in private (wilde scholen) HCS in Cirebon and Rembang for four years until 1938. Returning to Jakarta, he found other work and enrolled in the Rechtshogeschool to study law. Here too, though he was then unaware of it, he was also implicitly channeled into a Chinese tunnel. Although Yap eventually became one of Indonesia's most prominent professional advocates, neither in the Rechtshogeschool nor at the law faculty in Leiden did he think of joining the advocacy. It was not initially a calling for him but in time became one. As few ethnic Chinese were recruited into the colonial legal bureaucracy, the one profession clearly open to ethnic Chinese law students was private lawyering.

After working his way to the Netherlands on a repatriation ship in early 1946, Yap finished his law degree in Leiden in 1947. He did a great deal more than study law, however, which may have been less on his mind than religion and politics. Living at the Zendingshuis in Oogstgeest, just outside of Leiden, he read widely in modern Protestant theology and talked endlessly with students preparing for mission work. His commitment to the church, but also to his own independent reading of the religion, deepened. The church offered him further training at Selly Oakes in England if he would commit himself also to church work in Indonesia. He agreed and paid that debt many times over, beyond a period as a church youth leader in Jakarta during the late 1940s, in his dedicated labors in the reorganization of the Protestant churches and in the ecumenical movement (including the Council of Churches [DGI], now the Alliance of Churches [PGI]) in Indonesia.

Yap also became a committed nationalist during his Leiden period, opposing the Dutch effort to restore their colony and siding outspokenly (a tautology in Yap's case) with the revolution. In this he was neither alone nor in the majority among peranakan students in

\footnotetext{
${ }^{2}$ Yap first got an inkling of the discomforts of marginalization as his name kept changing: from Yap Thiam Hien to Thiam Hien Yap when his father converted to European legal status; Jaap when he moved to Java; and John as a nickname during the 1930s, when adopting European given names or nicknames was something of a fashion among the educated.

${ }^{3}$ But his younger brother, Bong, lived with the same family and never converted. His sister became Catholic after studying in a Catholic school in Banda Aceh. Yap was one of relatively few peranakan converts to Protestantism before the war, but explaining why he or others adopted the religion is not easy. The missiologist Hendrik Kraemer may have fathomed one basic reason for conversion among ethnic Chinese, particularly in Jakarta and Cirebon, by relating it to the noticeable decline of the extended family in those areas. The Chinese family, he reasoned, was fundamentally analogous to religion among other groups, and when it broke down, its members would be ready for conversion. See Hendrik Kraemer, From Missionfield to Independent Church (The Hague: Boekencentrum, 1958), pp. 149-58, on "The Chinese Question" in West Java.
} 
Holland. Peranakan Chinese were generally suspicious of politics under the best of conditions, and the news from home of anti-Chinese violence during the revolution was upsetting. But for Yap (as for his brother, who followed him to Holland) anticolonialism came easily, though thoughtfully, and nationalism no less so. There was never any doubt that he would return home nor that the revolution was right. At the same time, he began to develop a political orientation, basically democratic socialist, through his association with other Indonesian students connected with the Dutch Partij van de Arbeid (Labor Party). ${ }^{4}$

After returning to Jakarta in 1948, Yap packed a huge supply of life crises into a short year or so. He married. His father Sin Eng and Sato Nakashima both died in 1949. He worked in the church. And he decided to practice as a professional advocate, eventually joining a small but prominent law firm all of whose partners were publicly engaged in and beyond Chinese affairs. ${ }^{5}$ Yap was not likely to sit back. He saw himself as a public man, with too many ideas to ignore the mountain of difficult issues around him and too much energy to sit quietly in one office. Moreover, the relative lack of willing Chinese leaders placed a premium on the few who were available. Yet he was utterly unprepared for politics, without experience or essential knowledge, contacts, understanding, or even the suppleness of character and sense of easy compromise and humor that would have made him a quick political study.

Although the revolution eliminated the explicit ethnic segregation of political life, this change did not mean a great deal. Only a few peranakan Chinese joined national parties. Most of those who were at all inclined to act politically, themselves a small minority, knew or sensed that they either would not be welcome or would swing little weight. Yap joined neither the PSI nor the Protestant Parkindo, though he was invited into the latter by Dr. Leimena. Suspicious of insider politics and doubtful about the ethics of political life, he, moreover, refused to be bound by party discipline. In addition, he was afraid that ethnic Indonesians would not accept him at face value, a burden of doubt from which he was relieved only in the 1960s in the circle of professional advocates.

Despite his own nonethnic predilections, he had no choice but to retreat into the few Chinese opportunities for public service. What was available, apart from one or two ineffectual Chinese parties in which he had no interest, was the Sin Ming Hui, the social service association founded in 1946 that fed into each of the Chinese political organizations established thereafter. During the early 1950s, until Baperki came along, Yap worked for a legal assistance office sponsored by the Sin Ming Hui to advise ethnic Chinese, particularly on citizenship problems. It was the citizenship question, more than anything else, that drew Yap to grand issues of Indonesian state and society.

Citizenship marked peranakan vulnerability as nothing else could. It went to the heart of peranakan identity and security, preceding every other issue of significance to those who thought they belonged in Indonesia and nowhere else. No one could escape the abysmal

\footnotetext{
4It was not a surprising choice, of course. Many Indonesian professionals and intellectuals moved towards democratic socialism during this period. Among peranakan Chinese, a few joined the Indonesian Socialist Party (PSI), but most did not, probably mainly for ethnic reasons.

${ }^{5}$ All members of the firm were Chinese, as were its clients, a fairly common pattern until the 1960s. Yap's more senior partners included Lie Hwee Yoe, founder of the firm in the 1930s, the West Javanese Tan Po Goan, who had actively supported the revolution and become a member of the PSI, and the much younger Solonese Oei Tjoe Tat. Oei was prominent in the Sin Ming Hui, and later in Baperki and Partindo, and a member of Soekarno's cabinet from 1963 through early 1966, when he was imprisoned for over a decade. His politically active partners no doubt helped to educate Yap and to encourage his own public bent.
} 
threat posed in the ups and downs of the legal rules as they changed under political pressure nor, for that matter, the miserable, costly, and humiliating charges and treatment that accompanied the documentary requirements of each change. But any serious consideration of the citizenship question was bound to raise others about how and where peranakan Chinese fit in Indonesia.

During the early 1950s, such questions arose more insistently and openly than at any time thereafter in the then still-active peranakan press, above all Star Weekly in Jakarta. It was a time of uncertainty and surprise, when Chinese, lumped together without differentiation, became fair political game as an accessible, live symbol of colonial privilege. ${ }^{6}$ Chinese responses to the unsettling situation sorted along a continuum that included emigration, hard-nosed refusal to recognize any need for adaptation, and reflective, often painful soul searching, largely in the pages of Star Weekly, about peranakan Chinese history, culture, sins, virtues, exigencies, and about what must be done to adapt as a legitimate part of Indonesian life. In themselves, the discussions of that period are a fascinating study in intellectual history as commentators explored peranakan history and culture, the invidious effects of colonialism in molding the minority, and the problem of who had to adjust to whom and over what obstructions created either by ethnic Indonesian or ethnic Chinese mentalities. Yap himself wrote mainly about the law of citizenship but as an avid and thoughtful reader must have been absorbed in the debates.

Baperki was established in March 1954 as pressure grew on peranakan Chinese-above all the question of citizenship but also Chinese schools and commercial influence-and their lack of preparation to deal with it became apparent. ${ }^{7}$ It was the first organization to bring together nearly all strands of peranakan politics, though not all that effectively nor for long. Yap was a founding member, primarily as a representative of the Protestant stream. Auwyong Peng Koen, another HCK graduate, the capable and influential editor of Star Weekly, was there for Catholics. Still others spoke for the old right, left, and center of a thin political tradition begun in the 1910s. No less than before the war, successful peranakan Chinese leadership fell to those best connected with the regime, which in the colonial period meant the established wealth of the Chung Hua Hui but in the 1950s meant, in a dramatic shift of personnel and ideology, those who had joined the revolution.

A natural choice for chairman of Baperki was Siauw Giok Tjhan from Surabaya, a journalist, politically experienced on the left in the prewar, pronationalist Partai Tionghoa Indonesia (led by Liem Koen Hian), and briefly a minister in the revolutionary Amir Sjarifuddin cabinet in Yogya. Politically acute, well connected with and respected by national political leaders, Siauw turned Baperki into the most highly mobilized political organization ever of

\footnotetext{
${ }^{6}$ In August 1951, Liem Koen Hian (quoted at the beginning of this article), long a supporter of Indonesian nationalism and of the revolution, was arrested in the Sukiman anti-Communist razzia. Angry and bitter, he publicly rejected Indonesian citizenship. He remained in the country as a businessman but died soon after in Medan. The tragic incident rocked politically conscious peranakan Chinese, making any who were confident about their acceptance more aware of just how vulnerable even the most patriotic peranakan actually were.

7On Baperki see, among others, Mary F. Somers, "Peranakan Chinese Politics in Indonesia" (Ph.D. diss., Cornell University, 1965); idem, Peranakan Chinese Politics in Indonesia, (Cornell Modern Indonesia Project Interim Reports Series, Ithaca, N.Y. 1964); Charles A. Coppel, "Patterns of Chinese Political Activity in Indonesia," in The Chinese in Indonesia: Five Essays, ed., J. A. C. Mackie (Honolulu: University Press of Hawaii, 1976); and Go Gien Tjwan, "De historische wortels van de Baperki-beweging," in Buiten de Grenzen: Sociologische opstellen aangeboden aan Prof. Dr. W. F. Wertheim (Amsterdam: Boom Meppel, 1971).
} 
Indonesian Chinese, though without much more influence in the political system than before.

Baperki, which provided the setting for the Siauw-Yap debates, closely approximated general Indonesian political patterns. It was, for example, utterly dominated by Javanese peranakan and, significantly, by the politically dynamic, experienced, and mobilized East Javanese peranakan. No less in Baperki than the PNI, for instance, local, family, and personal intimacies bore weight, and often could be traced back over decades. ${ }^{8}$ Finally, like other parties, Baperki tended to circle increasingly tightly around the personal leadership of Siauw.

The peculiar situation of the peranakan minority entrapped Baperki in inextricable contradictions. In one example, often cited, Siauw persuaded the founders that the organization must be presented as multiethnic; hence its name, which emphasizes the citizenship issue but does not mention Chinese. Yap disagreed at first, typically on grounds that if it was a Chinese organization, it should say so, but he quickly came to recognize the symbolic significance of Siauw's stroke. A few non-Chinese were recruited into Baperki's councils, as the Sin Ming Hui before it had also done for the sake of protection. But the gesture remained a gesture. Baperki could be no more multiethnic than ethnic antagonisms would allow it to be, which was very little. Overwhelmingly, it was, and was understood to be, a Chinese organization.

Beyond this fundamental problem was another. Founded not as a party but as a "mass organization" in order to avoid ideological conflict among its members, in a short time, nevertheless, it was behaving much like a political party and paying the price in defections, internal conflict-much of it caused by Yap-and political disunity within the community it meant to represent. But the advantages of acting like a party were too attractive to ignore, as was true also of the apparent rewards for choosing ideological sides in the political system at large. The tensions caused by these developments defined the issues over which Siauw and Yap fought, and their bitter, protracted battles in turn helped to locate the varying dimensions and limits of peranakan participation in the Indonesian universe.

Oddly, despite appearances, the two men were much alike and in agreement on a few fundamentals that set them both apart from others, including close associates. Siauw, by far the more politically knowledgeable and experienced, was supple, personable, emotional, and intimate. The better educated and intellectually avid Yap, religiously devout, a loner, and not much given to small talk, tended toward rigid and uncompromising (and occasionally self-righteous) principle, rigorous logic, and detached argument. But both men were personally modest, unself-serving, serious, and responsible-qualities they recognized and respected in one another. Siauw was probably more comfortable with a Chinese identity, whereas Yap, who did not regret being Chinese, nevertheless took it more lightly. But neither was naive or particularly chauvinistic about the peranakan minority in Indonesia nor given to justifying the privileges many Chinese had gained in the colony and maintained thereafter. Both, indeed, tended to be censorious of bloated wealth, Chinese or other. They defended not Chinese commercial advantage but Chinese minority rights. ${ }^{9}$

\footnotetext{
${ }^{8}$ One example is the relationship between Siauw and Go Gien Tjwan. Given the closeness of many Javanese peranakan and priyayi families, it is not surprising that personal connections extended into the PNI and a few other organizations. Siauw himself, whatever his ideological affinity to the PKI, was personally quite close to Sartono, the PNI speaker of Parliament.

Yap was both impressed and puzzled by Siauw's defense of Chinese rice millers when they came under attack by government policy, for it indicated Siauw's even-handedness in protecting all Chinese, even if this seemed to
} 
Moreover, their defense of the minority's human rights did not stop there at all. From different starting points-Siauw's a Marxist critique, Yap's a more eclectically democratic socialist and idiosyncratically Christian-both assumed that Indonesian economy and society had to change in principle. On what kind of change was needed they disagreed monumentally, but each had principles that were significant beyond merely defending peranakan. Siauw, however, who won hands down in every conflict with Yap, ultimately could not escape the peranakan circle to speak to a larger Indonesia. Yap did.

Yap lost out in the Baperki struggles largely because of Siauw's greater political skill and appeal but also because he was rather alone, without effective support, without any of the connections that counted, and without much understanding of everyday politics. Always an outsider and a persistent stranger to the styles of Javanese peranakan politics-which is to say, Javanese politics-Yap never figured out how to play that game well. ${ }^{10} \mathrm{He}$ had nothing more, really, than substantial resources of personal courage, principle, and learning. Several of the liberal allies he found in Baperki in 1954 fled soon after the completeness of Siauw's control of the organization became clear. Partly out of unrealistic optimism but also from a stubborn disinclination to give up on anything, Yap stayed, biting heels until he was swept away in 1960. But Yap lost too because his vision of peranakan problems and solutions made less sense to many ethnic Chinese than did those of Siauw.

The issues in the Siauw-Yap debate ran a gamut from those having to do with Baperki, reflecting differences over how best to represent the peranakan minority, to political principles of the Indonesian state. Of the first order was Baperki's steady evolution into a political party, as Yap saw it, that assumed increasing responsibility for Chinese affairs. Yap did not object to the decision to contest the elections of 1955, which installed a specific voice for peranakan interests in Parliament and the Constituent Assembly. He himself took a seat in the Constituent Assembly, though technically not in Baperki's delegation but in the Fraksi Lima Orang, all of them Baperki members. But he did oppose any further extension of Baperki's political reach.

Why? The answer illustrates a fundamental disagreement over conceptions of the relationship between community and leadership and, by extension, between society and state. Siauw sought to mobilize unified support-even at the cost of defections-in defense of peranakan interests, for this seemed essential particularly during the period of Guided Democracy. Yap was more skeptical than Siauw about political possibilities and less willing to take risks on behalf of the peranakan community. In addition, however, he was convinced that the community itself, as much as possible, had to assume responsibility for its own affairs. ${ }^{11}$ This issue came to a head over the establishment of Res Publica University, sponsored by Baperki over Yap's fierce opposition.12

contradict his Marxist commitment to deprived classes. It is worth noting that Siauw got along quite well with the totok community, which trusted him and from which he evidently obtained substantial contributions for various Baperki projects. Yap had few contacts, if any, among totok Chinese and tended to distance himself from them. Neither Yap nor Siauw spoke Chinese.

${ }^{10}$ Although Yap's wife Khing was a Javanese speaker from Semarang, and servants in their home were Javanese, he never learned to speak or understand Javanese.

${ }^{11}$ In Yap's mind there may have been an analogy between the peranakan condition and that of the Protestant churches immediately after independence. In the church he had been instrumental in establishing a school system independent of the corporate church to separate their fates, and assure the schools' survival if the churches came under attack.

${ }^{12}$ The issue of principle was mixed with personal pique on Yap's part. Beginning in 1957, as alien Chinese schools came under attack, Baperki was able to take over and run many of them under its own umbrella. At the 
The same problem-to Yap's mind, how best to represent peranakan Chinese without making them more vulnerable-attached to the question of Baperki's support for the Communist party (PKI). A few complexities around this issue need sorting. Much was made of Siauw's Communist sympathies, not least by Yap, but Siauw's communism came with a lower case "c," and it is likely that the Chinese factor counted for more in his commitments than ideology. ${ }^{13}$ Yap was anti-Communist but not rabidly or unthinkingly so. His religious education in Oegstgeest and training for church work thereafter in Holland and England contained a strong anti-Communist bias. But he doubted party ideologies of any sort. He placed his trust mainly in personal character, which allowed him to respect Siauw as a man while challenging his political views and attachments. (Siauw reciprocated, admiring Yap for his honesty and courage even as he thought him a terrific pain.) ${ }^{14}$ Before the 1955 elections, Yap and Go Gien Tjwan, who he knew was Communist, campaigned as a team to demonstrate that men of different political views could work together. Yap thought this proved that Baperki was nonideological.

He fought bitterly with the Siauw group as Baperki seemed to move closer to the PKI after 1956. For Siauw, ideological attraction apart, what counted was that only the PKI among the major parties explicitly rejected ethnic bigotry and publicly supported Baperki initiatives. Moreover, PKI support for Soekarno, to whom Siauw attached great importance, also made sense of a political alignment with the party. But for Yap, though his own ideological biases naturally made a difference, the primary consideration was that the Chinese minority must not risk taking ideological sides. To do so would split the community more than it was already and envelop it in political danger. Baperki's drift to the left drove some of its most prominent centrist figures out and alienated more, yet it alone symbolically

same time, because of informal quota restrictions on the matriculation of ethnic Chinese students in the universities, it was agreed that a new university should be created in which there would be no discrimination against Chinese students. Yap was a member of the committee that set about organizing a private effort. Before it got far, however, the Baperki inner council-Siauw himself, Go Gien Tjwan, and the secretary, Buyung Saleh-quietly but quickly undertook their own effort, undercut that of Yap's committee, and successfully put together the land and funds to set up Res Publica University. Apart from his personal outrage at the flanking maneuver, Yap thought that by establishing its own university, Baperki endangered the school (and peranakan interests generally) by association. In this he eventually proved to be right. At the time, however, along with the urgent need for a university - and as well the ability of Siauw et al. to mobilize quickly the funds and energy it requirededucation was too important a political issue for Baperki leaders to allow anyone else to take credit for resolving it.

${ }^{13}$ Siauw evidently had been attracted to communism since the $1930 \mathrm{~s}$, when Tan Ling Djie, to whom he remained quite close, influenced his ideological education. Until 1953, he edited Harian Rakyat, after it had been sold to the PKI. Questions were raised about whether he was a secret member of the party, but in fact he may have resented the Aidit leadership for having ousted Tan Ling Djie, if Siauw thought this was inspired by anti-Chinese animus or too much sensitivity to anti-Chinese sentiments. See Siauw Giok Tjhan, Lima Jaman: Perwujudan Integrasi Wajar (Jakarta and Amsterdam: Yayasan Teratai, 1981), pp. 296-97. My point, however, is that Siauw was rather more devoted to the survival of peranakan Chinese than he was to communism. One of the issues between Yap and Siauw had to do with the latter's support of the People's Republic of China, which he visited, and to which he sent some of his children to study. Yap thought Siauw's connections with China were wrong, partly on ideological grounds but also because it reinforced the myth that Indonesian Chinese were loyal to China. Yap himself refused to go to China, though he was intellectually interested in it, precisely for this reason. It is an interesting question whether Siauw was attracted to China for ideological or ethnic-cultural reasons. Yap evidently thought the former influence more important, but it may well have been the latter.

${ }^{14}$ Siauw, Lima Jaman, p. 241. 
represented the entire minority. ${ }^{15}$ The danger was that in case of ideological warfare, the Chinese minority would be politically exposed and without a means to defend itself. ${ }^{16}$

The tensest battle between Siauw and Yap took place in 1959 over the issue of the restoration of the 1945 Constitution, which clearly demarcated their understandings of stakes and possibilities. Yap's thinking about minority issues took a critical turn as a result of this debate, which started in late 1956 and early 1957, as the parliamentary system collapsed and Soekarno pressed his Konsepsi. To clarify the implications of their divergence, however, it may help to call attention to the principles on which they agreed. Because they shared a commitment to human rights, including the Universal Declaration, both quite naturally asserted the rights of minorities. With different emphases, both also were essentially egalitarian. Neither had any taste for the corruption, inefficiency, economic waste, and self-aggrandizing tendencies of party conflict during the parliamentary period. ${ }^{17}$

But Siauw supported Soekarno, whereas Yap condemned Guided Democracy. In neither case was the position simple. Siauw was convinced that the parliamentary system had failed, that its insoluble conflict of ideologies and partisan advantage would lead to national disaster, and that adequate evidence for its dangers existed in the escalating attacks on the Chinese minority. Soekarno he knew to be free of prejudice, as were many PNI leaders associated with the president, and so was the PKI, which Soekarno insisted should be in the government. But beyond all this, Siauw was no less drawn to Soekarno and his vision than were many other Javanese. It is essential to recognize this Javanese influence in the trust that Siauw placed in Soekarno's person. Siauw believed that Indonesia needed revolutionary change, whose principles would secure the Chinese minority in a political-economic order from which ethnic issues would disappear, and that Soekarno was the key figure to bring all this about. Consequently, as Guided Democracy evolved, Siauw consistently brought Baperki along behind the president. Whatever his doubts about the 1945 Constitution, of which there must have been many, like others he brushed them aside for the sake of Soekarno's ascendancy.

Yap, however, worked from the lawyerly assumption that persons are less promising than sound institutions and legal processes. He too admired Soekarno as unprejudiced but stopped short of wanting to vest more authority in the man. Rather, he insisted that the most secure hope for Indonesia and its Chinese minority rested in effective law, which required the constitution to be taken more seriously than political figures. On this issue Yap and Siauw split completely. In the Constituent Assembly, every member of Baperki except Yap voted to restore the 1945 Constitution. Yap was the only member of the Konstituante to vote "no" contrary to his fraksi. Yap's opposition to the 1945 Constitution was not focused solely on Article 6, which provides that only an indigenous Indonesian may become president. ${ }^{18}$ This was an important issue, and one that had to trouble Baperki, which, as Yap

\footnotetext{
${ }^{15}$ In his dramatic speech to the Baperki congress of December 1960 in Semarang, Yap angrily accused the Siauw leadership of having driven out many of the respected founders of the organization. In fact, those who left initially were mainly from the Keng Po group: Auwjong Peng Koen, Khoe Woen Sioe, and Injo Beng Goat. Others on the center and center-right remained almost to the end but with little influence.

${ }^{16}$ As it happened, after 1965, Chinese suffered less than Yap feared precisely because the community was politically divided. Baperki, suddenly naked on the left, was obliterated, but its defectors and opponents were safe, active, and, in some cases, remarkably influential.

${ }^{17}$ The voluminous evidence for Siauw's views can be found in his Lima Jaman. Yap developed his arguments in writings scattered over the years from 1959 through 1988, but I am relying also on interviews with him.

${ }^{18}$ Actually, the objection on grounds of discrimination was to both Articles 6 and 26, the latter of which provides that "(1) Citizens are indigenous Indonesians and others certified [disahkan] as citizens by statute."
} 
argued, was established to fight against all forms of discrimination. What could be more discriminatory than Article 6? Unlike others in the organization, including Siauw, who tried to defuse the issue by waving it aside, Yap refused on principle to dismiss it. ${ }^{19}$ But Article 6 was not the end of Yap's case against the 1945 Constitution, as he made clear in May 1959 during the Konstituante debate:

The history of constitutional states is the history of the struggle of people against tyranny, despotism, and absolutism. The struggle for fundamental human rights and freedoms against absolute power. The constitution is a manifestation of the victory of justice over arbitrariness, the victory of "Recht" over "Macht." Therefore a constitution is intended to establish and guarantee in its body fundamental human rights and freedoms, to formulate and limit Government authority, and to control the exercise of that authority....

The history of the struggle for independence of the Indonesian people is also a struggle for the supremacy of "Law" over "Power," of justice over arbitrariness. Therefore, the Indonesian Constitution must share the same character and purpose as other constitutions.

What good were the sacrifices of the Indonesian people for the sake of independence, if Indonesians can still be detained at will, without knowing what they are guilty of, without trial, and then released just like that without the right to sue for revision and damages, just as in the colony?

What good are the sacrifices of the Indonesian people in the struggle for independence, if, as in the colonial period, Indonesians do not have the right and freedom to think, to write, to organize, to hold meetings, to join political parties, to act in opposition, to strike, and so on. ${ }^{20}$

And so on in the same vein. Yap detailed the shortcomings of the 1945 Constitution, particularly with respect to executive authority, and sharply criticized the limitation of rights already evident in the early Guided Democracy period. Finally, he excerpted from his earlier speech in the Constituent Assembly:

In English I once quoted the saying that ... if human beings were angels, then Government would be unnecessary. And I added: There would also be no need for Constitutions. But humans are not angels. Indeed, humans often do evil things, and do not always do virtuous things. We realize that all authority may be abused, and that as authority increases, so does its abuse. Consequently, humans in authority must have limits imposed on their authority in order to protect them against themselves and to protect others against them.

\footnotetext{
${ }^{19}$ In his memoirs, Siauw points out that in the preparatory committee discussions in August 1945, the initial draft of Article 6 required the president to be both Muslim and asli. On August 18, it was agreed that the religious qualification should be removed, for it was understood that as Indonesia's population is overwhelmingly Muslim, the president was bound to be a Muslim anyway. The same reasoning should have applied to the ethnic qualification, Siauw agrees, but no one raised the issue. At that session of the preparatory committee one peranakan member was present, Yap Tjwan Bing, later on the PNI council, but according to the record he did not object. See Muhammad Yamin, Naskah-Persiapan Undang-Undang Dasar 1945 (Jakarta: Yayasan Prapantja, 1959) 1: 402,418 . Siauw claimed in 1959 , repeating the point in his memoirs, that one reason for the asli qualification was to avoid the possibility that a Japanese president might be imposed. Siauw, Lima Jaman, p. 286. I know of no corroborating evidence for this assertion.

${ }^{20}$ Risalah Konstituante, 1959, Sidang ke-I, Rapat ke-12, May 12, 1959, 612-19, at 613-14.
} 
The debate over this issue, among others, transplanted to the Baperki Congress in Semarang in December 1960 led to Yap's departure from the organization. ${ }^{21}$ It also indicated Yap's departure from the strategic thinking of many peranakan leaders about the relationship of the Chinese minority to the Indonesian state. Siauw represented-or better, formulated-the choice of a substantial Javanese peranakan intellectual stratum to bet optimistically on the ability of Soekarno and his support on the left to bring about the fundamental change that would secure peranakan chances. But Yap, skeptical outsider and much puzzled by the intricacies of Javanese political habits, had little faith in this kind of prognosis. Moreover, he was already moving beyond peranakan grounds toward the larger and less confining arena of Indonesian state and society, a point to return to later.

One last debate over peranakan issues is worth recounting, in which Yap confronted not only Siauw but Siauw's critics, made up largely of "assimilators." It came to a head in the pages of Star Weekly in 1960, at a time when the Chinese minority was under attack, uncertain, and tense, largely as a result of the turmoil over the alien traders restrictions of 1959 (PP 10 [government regulation 10, 1959]) but also, still, in connection with issues of citizenship and education. In this period of angst, the long debate over peranakan choices sharpened considerably.

In Star Weekly, a group of ten well-known peranakan figures published a statement favoring voluntary "assimilation" as the way out of the minority dilemma. By this view, peranakan should in effect disappear through absorption by adopting "Indonesian" names, shedding Chinese distinctions, and becoming essentially "Indonesian." 22 After all, said its proponents, Chinese had long mixed biologically and culturally with indigenous Indonesians, and artificial obstacles to the continuing process, whether in the form of Chinese "exclusiveness" or anti-Chinese prejudice, should be eliminated. It was not an insensible position.

But it clashed frontally with the equally compelling "integrationist" view, which had it that the Chinese minority, no less than any other minority in a country made up of minorities, should be accepted as part of the Indonesian universe, without additional prejudicial encumbrances. This was Baperki's argument. Here Yap and Siauw were agreed, and both were particularly incensed by the proposal that Chinese should adopt "Indonesian" names. ${ }^{23}$ But agreement stopped there, for how integration was to be achieved divided Siauw and Yap (and many others) sharply. Siauw, again, was convinced that only a radical restructuring of Indonesian economy and society would make effective integration possible, for the problem, he believed, was a side effect of the economic injustice and exploitation

\footnotetext{
${ }^{21}$ At the Semarang Congress, Yap delivered a speech in which he attacked Siauw unremittingly for supporting the PKI and Soekarno. Siauw did not reply, but Yap was hooted down mercilessly by the membership and vilified personally in a speech by Buyung Saleh. Yap attended no meetings of Baperki thereafter, but he never resigned his vice-presidency or membership, insisting that he would have to be ousted formally, which Siauw and other officers refused to do. In 1968, when Yap was accused of Communist associations through his connection with Baperki, his speech at the 1960 Congress helped to vitiate the charge.

22 Star Weekly, March 26, 1960.

${ }^{23}$ Again and again in his memoirs Siauw returns to the name-changing issue, which he mistakenly attributes entirely to Catholic peranakan, castigating its proponents in undisguised anger and contempt. During the late 1960s, when the pressure on peranakan to adopt "Indonesian" names became particularly heavy, both from within and without the community, no one opposed it more fiercely than Yap, though the issue will not be taken up in detail here. I use quotation marks around "Indonesian" here simply to make the point that, from one perspective, in Indonesia "Chinese" names are no less "Indonesian" than "Batak," "Javanese," "Balinese," or "Menadonese" names.
} 
caused by colonialism and imperialism. ${ }^{24}$ Yap was equally convinced that the Communist cure he believed Siauw offered would kill all the patients.

In a series of articles for Star Weekly entitled "The Three Therapies," which stimulated more (and more acrimonious) correspondence than the journal had ever received, Yap attacked what he probably conceived as left and right extremes. ${ }^{25}$ In the first piece, published as a brief letter, Yap dismissed Siauw's "Communist" therapy partly on grounds that it was totalitarian and, therefore, ideologically unacceptable but also more subtly because opposition to it by the majority of Islamic and Christian Indonesians made it unrealistic. In the second letter, he challenged the "assimilationist" position of the ten tokoh (prominents). First, he wrote, although voluntary assimilation was one way of resolving the minority problem, there were other means of doing so: the legal elimination of all forms of discrimination and education in democracy and human rights, policies that would foster good racial and ethnic relations. Second, and more emphatically, social-political conditions and the temper of the country were not conducive to assimilation. In his criticism of both therapies, Yap eventually proved quite right, even prescient.

The third article, in which Yap offered his own solution, is remarkable for its acute analysis of the peranakan problem and of minority relations generally. In some ways it represents Yap at his best: detached, analytical, rigorous, even-handed, and unremittingly critical. Yap was most concerned here not with Siauw's argument but with that of the assimilators, which he probably (and correctly) thought the more dangerous illusion because it seemed more obvious and compellingly simple. Drawing on the work of Louis Wirth, Arnold Rose, Lévi-Strauss, the Declaration of Human Rights, and much else, he presented minorities as the creation of dominant majorities-defined by their power, as in the case of the Dutch colonial "majority" - that would themselves be affected by their treatment of minorities. In a concise comparative review of the experience of minorities around the world-Jews in Europe and blacks in the United States, among others-he pointed out that physical or cultural differences were the bases on which groups of citizens were turned into minorities. For this reason, he wrote, the ten tokoh wanted to get rid of the differences they perceived to be grounds for discrimination against peranakan. But were they right in supposing that this was the only way to do it? No, for Switzerland, Hawaii, the Soviet Union, and China demonstrated that national unity and coexistence were possible without a culturally destructive leveling (nivellering) in the kind of "brave new world" Hitler sought to create. ${ }^{26}$ Replying to the arguments of Lauw Tjoan Tho, one of the ten tokoh, Yap agreed that under optimum circumstances assimilation, as a multidirectional process of give-and-take, was desirable, but

assimilation of a minority into a "dominant group" cannot possibly be achieved if only the minority wishes it while this objective is rejected by the "dominant group." And if we do not hesitate to point out that at present there is a part of the "dominant group" that rejects assimilation of the Chinese minority, it is because the facts speak loud and

\footnotetext{
${ }^{24}$ Siauw's commitment to this analysis was genuine. In his memoirs he returns to it endlessly, to the point of making his autobiography more pedantic and boring than it ought to have been. Siauw, Lima Jaman, passim.

${ }^{25}$ Yap's three articles appeared in Star Weekly on April 16 and 30 and May 21, 1960. The critical responses, including one by Siauw, went on through June. Buyung Saleh wrote a generally vituperative but occasionally reasoned reply in the pages of Berita Baperki, May 15, 1960.

${ }^{26}$ Nazi Germany, which Yap thought the epitome of evil, was much on his mind during this period. In an original draft of the first installment of the "Three Therapies," a long introductory paragraph deals with "Nazifascists" and their treatment of Indonesian citizens of Chinese descent. In the published version, this paragraph and all references to "Nazi-fascists" are excised, probably at the request of Star Weekly's publishers.
} 
clear. Up to the present Indonesian citizens of Chinese descent still experience "restriction of employment opportunities, lack of access to facilities that are meant to serve the population in general, the presence of bias and antagonism among law enforcement officials and many other manifestations of prejudice" (Arnold Rose, UNESCO study). Can this "discrimination and exclusion" be regarded as signs of the acceptance of the proposal of Lauw Tjoan Tho et al.? If there is no discrimination based on physical and cultural differences, then there are no more minorities and no "dominant group." And if there are no minorities and dominant group, isn't the problem done with?... We do not oppose assimilation an sich. We are only trying to explain that assimilation, as a means of resolving the minority problem, is not now appropriate. For discrimination has damaged the relations between groups, and bad interrelations are not the right soil and climate for the cultivation and sprouting of assimilation.27

After following a clearheaded and sustained argument for several impressive passages, however, suddenly the conclusion takes an astonishing leap into an abyss of confusion as Yap proposes his own way out. It may indicate how many blind alleys thinkers about the minority problem ran into and how desperate they were for promising solutions. Having rejected simple structural and simpler assimilationist analyses, Yap decided that "the problem is man himself," and his diagnosis was that the human soul is sick. The remedy was "Not 'brainwashing' but 'heart-cleansing'; not a change in the structure of society but a change from the materialistic and homocentric to a Christocentric view of man; not the elimination of physical and cultural differences, but the elimination of prejudice, egoism, and hypocrisy; that there no longer be a 'dominant group' but instead a 'ministering elite' (dienende elite); not the retooling of man, but the rebirth of man in Jesus Christ." 28

Yet in the dizzying unreality of this statement, there is an inkling of another solution that helped to pave Yap's road out of the confinement of ethnic politics and attachments.

Even among peranakan intellectuals and professionals, Yap was less well suited than most, and uncomfortable, in a world defined mainly by ethnic boundaries. By upbringing, education, culture, and experience he had little reason to feel at home in a Chinese, or even "Indonesian-Chinese," setting. He found himself there, as a public man, largely for lack of an alternative that offered no resistance either in a larger Indonesian universe or in his own mind. Siauw, more experienced and familiar in the peranakan (and totok) world, used his knowledge of and connections in the political system to incorporate the minority into national politics. Ultimately, however, his position in Baperki and his devotion to its causes, though it did not narrow his ideological commitments, did limit the reach of his voice. $\mathrm{He}$ donned an identity and was held to it. Yap, who had more reluctantly accepted the same identity, was less bound by it and freer to pursue an ideological course that was not exactly

27Yap, "Three Therapies," from the typescript version, p. 7. Yap goes on: "That assimilation of individuals has occurred in the past, now too, and will in the future, despite everything, cannot be denied. But these... exceptions prove the rule."

${ }^{28}$ Star Weekly, May 21, 1960, p. 6; p. 7 of the original typscript manuscript. What exactly was in Yap's mind when he wrote this and to whom precisely he directed it is not at all clear. Did he mean that Chinese had to turn to Christ or that all Indonesians should do so? Did he really believe any of this made sense? or did he, failing all else, simply fall back on the religious purpose that had become so important in his own life? We never talked about the article, at least not directly, and so I have no idea what he meant. It was, however, a time of great stress for him because of his battle within Baperki, his anger at the politics of Guided Democracy, and his anxieties over the persecution of Chinese. The church, in which, as always, he was hard at work on other matters, may have been the one place where he found any satisfaction. 
divorced from, but independent of, the accident of having been born Chinese. Ideologically, he was capable of thinking beyond the interests of the Chinese community to consider the character of Indonesian state and society, as his discussions in the "Three Therapies" show. So, clearly, was Siauw, though politically Siauw risked principle for what appeared to be political necessity. Yap stuck to principle, partly because he was in a better position to do so but also because he had little else to fall back on.

The ideology that finally counted, however, was not Christianity, which was another blind minority alley, but law. Once squeezed out of Baperki, Yap did not put the peranakan problem out of mind but, with a slight push, leapt to a different, Indonesian, stage on which minority questions were significant but submerged in a more complex network fashioned from rule of law and human rights issues.

If, as he argued in Star Weekly, the minority problem was largely a "dominant group" problem, then it had to be approached through an opening of principle to the Indonesian state and its responsibilities to Indonesian society. This turn of thought entailed another, which was perhaps more important-the problems of the Chinese minority were not sui generis. They could not, or should not, be construed separately from human rights problems generally. The appropriate struggle was not for Chinese alone, but for all Indonesians.

Yap's own opening was through the professional advocacy. He became widely known beyond the peranakan community quite suddenly, in 1966, for his defense of Subandrio before the Military Tribunal-Extraordinary. Instead of a pro forma show, Yap turned out a stunning defense replete with fine legal edges, which the judges ignored, and powerful political criticism, which the audience did not. Yap had appeared, with another advocate, in the name of PERADIN, the Indonesian Association of Advocates. Although a founding member of PERADIN in 1963-64, he remained uncertain that indigenous Indonesian advocates could ever accept a peranakan colleague on equal terms. It was more his problem than theirs. Few senior advocates of that generation-of the character of Lukman Wiriadinata, Hasjim Mahdan, Soemarno P. Wirjanto, Ani Abas Manoppo, Suardi Tasrif, and otherswere much infected by ethnic bigotry. ${ }^{29} \mathrm{Or}$, to the extent that they were infected, professional and collegial loyalties nevertheless took precedence. In PERADIN, at long last, even more perhaps than in the church, which itself remained troubled by ethnic cleavage, Yap found the kind of nonethnic setting that helped free him from the suffocating asthma of ethnic identity. The proof came in 1968, when Yap himself was illegally detained by a corrupt prosecutor and police official whom he had accused of extortion. After his release, they had him prosecuted for criminal libel. His PERADIN colleagues-Zainal Abidin, Djamaluddin Singomangkuto, and Hasjim Mahdan-stepped forward voluntarily to defend him. For the skeptical Yap, who always respected action' more than words alone, it was revelation and liberation, more important to him, I suspect, than he ever admitted to his attorneys. Thereafter, his closest friends came from the intimate circle of senior professional advocates.

Thereafter, too, he spent less and less time on Chinese issues and more and more on those of legal process and human rights. The last major Chinese issue he took up had to do

\footnotetext{
${ }^{29}$ The point is worth making that in general, the higher reaches of the priyayi class to which most senior advocates were born had always gotten along quite well, even intimately, with Javanese peranakan. It was for this reason that during the parliamentary period, when priyayi scions dominated the political elite, the Chinese minority, though under pressure, could expect more sympathy and help than was the case later, when middleclass elements that had long competed with and were hostile to Chinese economic advantage rose to prominence, particularly via the army.
} 
with the controversy over pressure to adopt "Indonesian" names, which he continued to excoriate unequivocally. ${ }^{30}$ It was not that Yap had lost interest, by any means, and when the occasion arose, he remained adamant in defense of Chinese citizens but now as citizens more than as an isolated minority and more as a general principle of human rights than as a specific issue in ethnic relations. This position followed naturally from his own political evolution. Liberated from the rigid limits of ethnic identity, he himself now spoke as an Indonesian citizen.

He spoke, moreover, and acted with all the courage, bluntness, forthrightness, passion, and tenacity that had driven his antagonists in Baperki (and occasionally in church circles) to distraction. In PERADIN, the Legal Aid Institute, the Institute for the Defense of Human Rights, in the press, parliament, in court, in the World Council of Churches and the International Commission of Jurists, and elsewhere, he simply never stopped-to the day of his death in April 1989-defending imperative values of human rights and justice. He became a living symbol of the human rights struggle, widely known and appreciated for his integrity, courage, and refusal to be quiet. Beyond a certain point, few thought of him any longer as the Chinese Yap. The thousands who paid respects at his funeral and the activist students who shouted then that Yap belonged to the nation clearly thought of him as a special kind of Indonesian, not a peculiar kind of Chinese. By the end of his life, Yap himself felt comfortable with this view.

\footnotetext{
${ }^{30}$ By this time, in the early New Order, Baperki was gone, its leadership scattered among various jails and prisons. Siauw was detained until the mid-1970s, when he was released and went to Holland, where he died in the 1980s. He and Yap had one last, rather miserable confrontation in 1980, in Holland, where Yap had gone to receive an honorary degree from the Vrije Universiteit. At a meeting of Indonesian Chinese immigrants to which Yap was asked to speak, with Siauw present, he harshly condemned the political consequences that Baperki bequeathed to the citizens of Chinese descent. Siauw, perhaps angry but undoubtedly hurt, briefly defended the organization's achievements.
} 